\title{
Peningkatan Pelayanan Kesehatan Puskesmas Untuk Penanggulangan Penyakit Tropis Demam Berdarah Dengue Andi Umardiono ${ }^{1}$, Andriati ${ }^{2}$, Nanang Haryono ${ }^{3}$
}

1Departemen Bisnis, Fakultas Vokasi, Universitas Airlangga. E-mail: andy.umardiono1972@gmail.com 2Departemen Rehabmedik, Fakultas Kedokteran, Universitas Airlangga,

E-mail: andriati1961.unair@gmail.com

3Departemen Administrasi, Fisip, Universitas Airlangga, E-mail: nanang.haryono@fisip.unair.ac.id

\section{ARTICLE INFO}

Keywords: Improvement of Health Services,

Health Centers,

Prevention, Dengue

Hemorrhagic Fever

Kata kunci:

Peningkatan Pelayanan

Kesehatan, Puskesmas,

Pencegahan, Demam

Berdarah Dengue

How to cite:

Umardiono, A.,

Andriati, \& Haryono,

N. (2018). Peningkatan

Pelayanan Kesehatan

Puskesmas Untuk

Penanggulangan

Penyakit Tropis

Demam Berdarah

Dengue. JAKPP (Jurnal

Analisis Kebijakan dan

Pelayanan Publik), 60-

67.

\section{ABSTRACT}

Preventive services to overcome tropical diseases of dengue hemorrhagic fever are very important. Optimization of the role of puskesmas needs to be improved, especially health educators in the efforts of preventive services. The purpose of this journal writing is to improve health services for health centers in tackling dengue hemorrhagic fever through counseling as a preventive measure. This study uses qualitative methods that prioritize the depth of research. Data is collected through interviews, observation and documentation. Data analysis using interactive model qualitative analysis. The results of the study, preventive health promotion services through local wisdom delivered by health educators at health centers are effective in changing the behavior and culture of the community for prevention of dengue can be optimized. The conclusion of this study is the public service of health counseling that synergizes with other stakeholders such as kyai and village heads are more effective in improving health services through preventive efforts to overcome tropical diseases with dengue hemorrhagic fever.

\begin{abstract}
Abstrak
Layanan preventif menanggulangi penyakit tropis demam berdarah dengue sangat penting. Optimalisasi peran puskesmas perlu ditingkatkan terutama penyuluh kesehatan dalam upaya layanan preventif. Tujuan penulisan jurnal ini adalah peningkatan pelayanan kesehatan puskesmas dalam penanggulangan penyakit tropis demam berdarah dengue melalui penyuluhan sebagai upaya preventif. Penelitian ini menggunakan metode kualitatif yang mengutamakan kedalaman penelitian. Data dikumpulkan melalui wawancara, observasi dan dokumentasi. Analisis data menggunakan analisis kualitatif model interaktif. Hasil penelitian, pelayanan preventif promosi kesehatan melalui kearifan lokal yang disampaikan petugas penyuluh kesehatan puskesmas efektif mengubah perilaku dan budaya bersih masyarakat untuk pencegahan DBD bisa dioptimalkan. Kesimpulan dari penelitian ini adalah pelayanan publik penyuluhan kesehatan yang bersinergi dengan stakeholder lain diantaranya kyai dan kepala desa lebih efektif dalam peningkatan layanan kesehatan melalui upaya preventif penanggulangan Penyakit Tropis demam berdarah dengue.
\end{abstract}

Copyright @ 2018 JAKPP. All rights reserved.

\section{Pendahuluan}

Berdasarkan data internal Pencegahan dan Pengendalian Penyakit, pada tahun 2015, penderita demam berdarah di 34 provinsi di Indonesia sebanyak 129.179 orang, dimana 1.240 diantaranya meninggal dunia. Pada bulan Januari- 
Februari 2016 Kementerian Kesehatan RI mencatat jumlah penderita Demam Berdarah Dengue di Indonesia sebanyak 8.487 orang penderita DBD dengan jumlah kematian 108 orang. Golongan terbanyak yang mengalami DBD di Indonesia pada usia 5-14 tahun mencapai 43,44\% dan usia 15-44 tahun mencapai 33,25\% (http://www.depkes.go.id/article/print/16030700001/wilayah-DBDdbd-ada-di-11-provinsi. html). Melihat kondisi yang cukup mengkhawatirkan ini, Kementerian Kesehatan melalui dinas-dinas Kesehatan di seluruh Indonesia lebih gencar melakukan Gerakan "1 Rumah 1 Jumantik". Gerakan ini merupakan program pemberantasan sarang nyamuk yang mengajak seluruh masyarakat berperan aktif dalam mencegah perkembangbiakan nyamuk, khususnya jentik nyamuk Aedes Spp. Berangkat dari pemikiran inilah penelitian peningkatan pelayanan kesehatan puskesmas untuk penanggulangan penyakit tropis demam berdarah dengue. Tujuan penelitian adalah mendeskripsikan pelayanan kesehatan puskesmas untuk penanggulangan penyakit tropis demam berdarah dengue.

Sebagai upaya untuk mempertegas hak dan kewajiban setiap warga Negara dan penduduk serta terwujudnya tanggung jawab negara dan korporasi dalam penyelenggaraan pelayanan publik, diperlukan norma hukum yang memberi pengaturan secara jelas, sebagai upaya untuk meningkatkan kualitas dan menjamin penyediaan pelayanan publik sesuai dengan asas-asas umum pemerintahan dan korporasi yang baik serta untuk memberi perlindungan bagi setiap warga Negara dan penduduk dari penyalahgunaan wewenang didalam penyelenggaraan pelayanan public (Irmawati, dkk).

Puskesmas merupakan organisasi fungsional yang menyelenggarakan upaya kesehatan yang bersifat menyeluruh, terpadu, merata, dapat diterima dan terjangkau masyarakat, dengan peran serta aktif masyarakat dan menggunakan hasil pengembangan ilmu pengetahuan dan teknologi tepat guna, dengan biaya yang dapat dipikul oleh pemerintah dan masyarakat. Upaya kesehatan tersebut diselenggarakan dengan menitikberatkan kepada pelayanan untuk masyarakat luas guna mencapai derajat kesehatan yang optimal, tanpa mengabaikan kualitas kepada perorangan.

Puskemas merupakan unit pelaksana teknis kesehatan di bawah supervisi Dinas Kesehatan Kabupaten/Kota. Secara umum, mereka harus memberikan pelayanan preventif, promotif, kuratif sampai dengan rehabilitatif baik melalui Upaya Kesehatan Perorangan atau Upaya Kesehatan Masyarakat. Puskesmas dapat memberikan pelayanan rawat inap selain pelayanan rawat jalan. Untuk dapat memberikan pelayanan yang baik tentunya selalu diusahakan adanya peningkatan kualitas layanan guna mencapai derajat kesehatan yang optimal bagi seluruh masyarakat. Keberadaan puskesmas sangat bermanfaat bagi keluarga tidak mampu. Melalui adanya puskesmas, setidaknya dapat menjawab kebutuhan pelayanan kesehatan yang memadai yakni pelayanan kesehatan yang mudah dijangkau. Puskesmas berfungsi sebagai: 1) Pusat penggerak pembangunan berwawasan kesehatan; 2) Puskesmas pemberdayaan keluarga dan masyarakat; dan 3) Pusat pelayanan kesehatan strata pertama. Secara umum, pelayanan kesehatan yang diselenggarakan oleh puskesmas meliputi pelayanan kuratif (pengobatan), preventif (pencegahan), promotif (peningkatan kesehatan) dan 
rehabilitasi (pemulihan kesehatan). Berdasarkan paparan data diatas, permasalahan penelitian yang ingin dijawab adalah adalah bagaimana peningkatan pelayanan kesehatan puskesmas untuk penanggulangan penyakit tropis demam berdarah dengue dengan upaya preventif.

\section{Kajian Literatur}

Demam berdarah adalah demam yang muncul dengan gejala sakit kepala, suhu tinggi, nyeri otot / tulang dan penurunan trombosit. Demam berdarah adalah penyakit virus, yang memiliki empat stereotip (DENV-1 hingga DENV-4) dan ditularkan melalui nyamuk betina yang dikenal sebagai Aedes Aegypti. Komplikasi berat demam dengue termasuk Demam Berdarah Dengue dan Dengue Shock Syndrome (Guzman, 2002). Demam berdarah dengue memiliki gejala suhu tinggi, perdarahan, jumlah trombosit yang rendah dan kebocoran plasma karena rendahnya konsentrasi protein dan albumin dalam darah. Dengue shock syndrome dapat terjadi setelah 2-7 hari demam berdarah dengue bersamaan dengan gejala tekanan darah rendah dan denyut nadi (http:/ / www.depkes.go.id/article/print/16030700001/wilayah-DBD-dbd-ada-di11-provinsi. html).

\section{Metode Penelitian}

Penelitian ini menggunakan pendekatan penelitian kualitatif. kualitatif dianggap tepat digunakan dalam penelitian penanggulangan penyakit tropis berbasis perilaku dan budaya lokal masyarakat. Lokasi penelitian dipilih Kabupaten Jombang dan Kabupaten Malang yang ditetapkan sebagai wilayah endemik DBD sebagai salah satu penyakit tropis. Unit analisis penelitian adalah stakeholder pengelola lembaga puskesmas. Penelitian ini adalah penelitian kualitatif deskriptif. Agar pengumpulan data dan informasi berjalan efektif dan efisien dilakukan dengan tahapan yaitu wawancara mendalam, kuisioner, observasi dan dokumentasi. Pemeriksaaan keabsahan data pada penelitian ini digunakan teknik triangulasi sumber data. Penelitian ini menggunakan teknik analisis data kualitatif model interaktif mengikuti Miles dan Huberman (1992).

\section{Hasil dan Pembahasan}

\section{Lembaga Pelayanan Kesehatan Puskesmas}

Pusat Kesehatan Masyarakat (Puskesmas) fasilitas pelayanan kesehatan yang menyelenggarakan upaya kesehatan masyarakat dan upaya kesehatan perseorangan tingkat pertama, dengan lebih mengutamakan upaya promotif dan preventif, untuk mencapai derajat kesehatan masyarakat yang setinggi-tingginya di wilayah kerjanya (Permenkes No.75 Tahun 2014). Pelayanan puskesmas merupakan bagian pelayanan publik. Ratminto dan Winarsih (2005) berpendapat bahwa "pelayanan publik atau pelayanan umum sebagai segala bentuk jasa pelayanan, baik dalam bentuk barang publik maupun jasa publik yang pada prinsipnya menjadi tanggungjawab dan dilaksanakan oleh instansi pemerintah di 
pusat, di daerah, dan lingkungan Badan Usaha Milik Negara (BUMN) atau Badan Usaha Milik Daerah (BUMD), dalam upaya pemenuhan kebutuhan masyarakat maupun dalam rangka pelaksanaan ketentuan peraturan perundang-undangan". Dengan demikian pengertian pelayanan publik puskesmas dapat dipahami sebagai segala bentuk jasa pelayanan yang menjadi tanggungjawab dan dilaksanakan oleh instansi pemerintah di daerah dalam upaya pemenuhan kebutuhan masyarakat maupun dalam rangka pelaksanaan ketentuan peraturan perundang-undangan. Pelayanan kesehatan yang diberikan puskesmas merupakan pelayanan yang menyeluruh yang meliputi pelayanan kuratif (pengobatan), preventif (pencegahan), promotif (peningkatan kesehatan) dan rehabilitatif (pemulihan kesehatan).

Sesuai dengan Permenkes No.75 Tahun 2014 tentang Puskesmas, pelayanan puskesmas meliputi pelayanan masyarakat dan perorangan. Upaya Kesehatan Masyarakat yang selanjutnya disingkat UKM adalah setiap kegiatan untuk memelihara dan meningkatkan kesehatan serta mencegah dan menanggulangi timbulnya masalah kesehatan dengan sasaran Keluarga, Kelompok dan Masyarakat. Upaya Kesehatan Perseorangan yang selanjutnya disingkat UKP adalah suatu kegiatan dan atau serangkaian kegiatan pelayanan kesehatan yang ditujukan untuk peningkatan, pencegahan, penyembuhan penyakit, pengurangan penderitaan akibat penyakit dan memulihkan Kesehatan Perseorangan.

Prinsip penyelenggaraan puskesmas meliputi: a) Paradigma Sehat; b) Pertanggungjawaban wilayah; c) Kemandirian Masyarakat; d) Pemerataan; e) Teknologi tepat guna; dan f) Keterpaduan dan Kesinambungan. Adapun tugas, fungsi dan wewenang puskesmas dipaparkan sebagai berikut. Tugas Puskesmas adalah melaksanakan kebijakan kesehatan untuk mencapai tujuan pembangunan kesehatan di wilayah kerjanya dalam rangka mendukung terwujudnya Kecamatan Sehat. Dalam melaksanakan tugas, Puskesmas menyelenggarakan Fungsinya a)Penyelenggaraan UKM tingkat pertama di wilayah kerjanya; b)Penyelenggaraan UKP tingkat pertama di wilayah kerjanya. Wewenang Puskesmas diantaranya adalah a) Melaksanakan perencanaan berdasarkan analisis masalah kesehatan masyarakat dan analisis kebutuhan pelayanan yang diperlukan; b) Melaksanakan advokasi dan sosialisasi kebijakan kesehatan; c) Melaksanakan komunikasi, informasi, edukasi dan pemberdayaan masyarakat dalam bidang kesehatan; d) Menggerakkan masyarakat untuk mengidentifikasi dan menyelesaikan masalah kesehatan pada setiap tingkat perkembangan masyarakat yang bekerjasama dengan sektor lain terkait; e) Melaksanakan pembinaan teknis terhadap jaringan pelayanan dan upaya kesehatan berbasis masyarakat; f) Melaksanakan peningkatan kompetensi sumber daya manusia Puskesmas; g) Memantau pelaksanaan pembangunan agar berwawasan kesehatan; h)Melaksanakan pencatatan, pelaporan dan evaluasi terhadap akses mutu dan cakupan Pelayanan Kesehatan; i)Memberikan rekomendasi terkait masalah kesehatan masyarakat, termasuk dukungan terhadap Sistem Kewaspadaan Dini dan Respon Penanggulangan Penyakit. Dalam menyelenggarakan fungsi UKP, Puskesmas berwenang untuk: a)Menyelenggarakan Pelayanan Kesehatan Dasar secara Komprehensif, 
berkesinambungan dan bermutu; b)Menyelenggarakan Pelayanan Kesehatan yang mengutamakan upaya promotif dan preventif; c)Menyelenggarakan Pelayanan Kesehatan yang berorientasi pada individu, keluarga, kelompok dan masyarakat; d)Menyelenggarakan Pelayanan Kesehatan yang mengutamakan keamanan dan keselamatan pasien, petugas dan pengunjung; e)Menyelenggarakan Pelayanan Kesehatan dengan prinsip koordinatif dan kerja sama inter dan antar profesi; f) Melaksanakan Rekam Medis; g)Melaksanakan pencatatan, pelaporan dan evaluasi terhadap mutu dan akses Pelayanan Kesehatan; h)Melaksanakan peningkatan Kompetensi Tenaga Kesehatan; i) Mengkoordinasikan dan melaksanakan pembinaan fasilitas pelayanan kesehatan tingkat pertama di wilayah kerjanya; j) Melaksanakan penapisan rujukan sesuai dengan indikasi medis dan Sistem Rujukan.

\section{Penaggulangan Penyakit DBD}

Penanggulangan dilakukan dengan tujuan menurunkan frekuensi DBD, menurunkan jumlah kasus dan kematian dalam suatu DBD, serta membatasi penyebar luasan wilayah DBD. Salah satu upaya penanggulangan DBD adalah pelaksanaan Sistem Kewaspadaan Dini (SKD) DBD. Adapun langkah yang dilakukan dalam pelaksanaan SKD DBD penyakit antara lain : (1) Penetapan daerah rawan DBD penyakit; (2) Penetapan bulan atau minggu rawan DBD (saat terjadinya peningkatan kasus) berdasarkan data epidemiologi beberapa tahun sebelumnya; (3) Penetapan unsur dasar penyebab terjadinya DBD berdasar hasil kajian epidemiologi; (4) Rencana kegiatan untuk menghadapi kemungkinan terjadinya DBD dan kesiapan penanggulangan serta intervensi faktor risikonya; (5) Pemantauan terhadap kesakitan dan kematian kasus yang dinamis (dengan grafik dan tabel mingguan secara ketat (laporan mingguan kasus); (6) Pemantauan terhadap kondisi lingkungan, perilaku masyarakat, dan pelayanan kesehatan; (7) Penyelidikan daerah rawan DBD atau dugaan terjadinya DBD.

Kesiapsiagaan menghadapi DBD pada saat ancaman peningkatan kasus dengan: (1) Mengingatkan petugas dan masyarakat kemungkinan DBD, tindakan pencegahan dan penanggulangan yang harus dilakukan; (2) Peningkatan aktivitas surveilans; (3) Tindakan cepat pada peningkatan kasus yang cenderung DBD serta pemberian pengobatan untuk mempercepat penyembuhan sehingga penderita tidak menjadi sumber penularan. Apabila hasil pengamatan dari pencatatan kejadian penyakit menular ternyata memberikan kecurigaan adanya DBD, maka perlu dilakukan Penyelidikan Epidemiologi (PE) yaitu semua kegiatan yang dilakukan untuk memastikan adanya penderita penyakit yang dapat menimbulkan DBD, mengenal sifat-sifat penyebab dan faktor-faktor yang dapat mempengaruhi terjadinya dan penyebarluasan DBD.

Data epidemiologi yang dikumpulkan berupa data primer dan dan data sekunder. Data primer berupa kuesioner pertanyaan " $5 \mathrm{~W} 1 \mathrm{H}^{\prime}$ yaitu What (apa, riwayat sakit), When (kapan waktu kejadian), Who (kelompok umur, kelompok pekerjaan, jenis kelamin, status imunisasi), Where (di mana tempat kejadian, dusun, desa, kecamatan yang terpapar), Why (mengapa bisa terjadi DBD), dan How (bagaimana mereka bisa tertular). Sedangkan data sekunder adalah berupa 
data kasus periode sebelumnya (paling tidak 1 tahun sebelumnya atau pola penyakit (grafik minimal dan maksimal), data vektor, data lingkungan, dan data perilaku penduduk.. Data vektor yaitu jenis, tempat perindukan, dan perilaku vektor. Data lingkungan yaitu data sumber air bersih dan lingkungan tempat kasus berada. Data perilaku penduduk yaitu kebiasaan penggunaan air bersih dan kebiasaan buang air. Data sekunder digunakan untuk membandingkan kejadian yang sekarang dengan periode sebelumnya atau periode yang sama.

Hasil penyelidikan berupa data epidemiologi, data vektor, data lingkungan, dan data perilaku penduduk kemudian dianalisis secara komprehensif untuk mengetahui dinamika penularan serta penunjang keputusan rencana tindakan penanggulangan DBD secara efektif dan efisien. Untuk mengetahui dinamika penularan, pembuatan peta situasi dusun/desa tempat terjadinya DBD diperlukan untuk menggambarkan hubungan antara kasus dengan faktor risiko lingkungan. Pada penyakit Demam Berdarah Dengue, kasus penyakit tesebut dapat dinyatakan DBD apabila memenuhi kriteria sebagai berikut (1) Terjadi peningkatan kasus di desa/kelurahan 2 (dua) kali atau lebih dalam satu minggu dibanding minggu sebelumnya berdasarkan common sense; (2) Bila dalam kurun waktu 3 (tiga) minggu berturut - turut cenderung terjadi peningkatan kasus secara epidemiologis bermakna; (3) Satuan epidemiologis DBD adalah desa/kelurahan.

Apabila terjadi kasus DBD / tersangka DBD, maka dilakukan Penyelidikan Epidemiologi (PE) oleh petugas Puskesmas/koordinator P2M/paramedis. Setelah dilakukan PE, data dianalisis untuk mengetahui letak permasalahanyang ada. Agar analisis dapat dilakukan dengan baik, PE harus memuat instrumen data sebagai berikut: (1) 1. Identifikasi transmisi penyakit yang dibuktikan dengan adanya penderita panas $>3$ orang dan adanya jentik di sekitar rumah. (2). Jumlah populasi terancam di dukuh/RW/desa) untuk mendukung attact rate; (3) Jumlah kasus dan meninggal untuk menghitung attack rate dan case fatality rate (CFR); (4) Sumber penularan (import atau indigenous); (5) Kepadatan vektor berupa angka bebas jentik, container index, dan house index; (6) Mengetahui risiko penularan penderita dengan melihat perilaku untuk upaya pencegahan.

Bila terbukti ada transmisi penyakit, harus segera dilakukan pemutusan rantai penularan dengan cara: (1) Membunuh nyamuk dewasa dengan melakukan fogging focus; (2) Membunuh jentik dan telur - telurnya dengan Pemberantasan Sarang Nyamuk (PSN) dengan program 3M, yaitu: a. Menguras tempat-tempat penampungan air secara teratur sekurangkurangnya seminggu sekali atau menaburkan bubuk abate kedalamnya. b. Menutup rapat-rapat tempat penampungan air. c. Mengubur/menyingkirkan barang-barang bekas yang dapat menampung air hujan, seperti : kaleng-kaleng bekas, plastik dan lain-lain.

\section{Peningkatan Pelayanan Kesehatan Melalui Penyuluhan Preventif DBD}

Pengendalian nyamuk bisa dilakukan dengan cara mekanis yaitu dengan cara menghilangkan sarang nyamuk, membersihkan kontaner, tambak dan sebagainya, membersihkan lingkungan. Pengendalian fisika dengan cara penyiaran radiasi, pengendalian hayati dengan cara memakai predator atau parasit. Pengendalian biologidengan pengendalian vector nyamuk dengan 
menggunakan bakteri pathogen [8]. Pemberantasan vektor terdorong dari fogging, abatisasi, pengawasan kualitas lingkungan, dan pembersihan sarang nyamuk (PSN). Kegiatan fogging adalah pemberatasan nyamuk demam berdarah menggunakan insektisida dengan cara pengasapan. Insektisida yang digunakan ialah malathion dengan campuran solar. Pengasapan sangat efektif dalam memutuskan rantai penularan karena semua nyamuk termasuk yang aktif mati seketika bila kontak dengan partikel-partikel insektisida. Dengan demikian penularan dengan segera dapat diputuskan Namun bila nyamuk Ae.ageypti tidak dibasmi, penularan akan berulang kembali bila ada penderita viremia baru.

Pembersihan Sarang Nyamuk (PSN) pada dasarnya, untuk memberantas jentik atau mencegah agar nyamuk tidak dapat berkembang biak. Mengingat aedes aegypti tersebar luas, maka pemberantasannya perlu peran aktif masyarakat khususnya memberantas jentik aedes aegypti di rumah dan lingkungannya masing-masing. Cara ini adalah suatu cara yang paling efektif dilaksanakan karena: a) tidak memerlukan biaya yang besar; b) bisa dilombakan untuk menjadi daerah yang terbersih; c) menjadikan lingkungan bersih; d) budaya bangsa Indonesia yang senang hidup bergotong royong; e) dengan lingkungan yang baik tidak mustahil, penyakit lain yang diakibatkan oleh lingkungan yang kotor akan berkurang. Dengan demikian langkah penting dalam upaya pemberantasan DBD melalui upaya PSN ialah memberikan penyuluhan kepada masyarakat yang intensif. Pokok-pokok pesan penyuluhan yang disampaikan meliputi pengenalan tanda-tanda, gejala-gejala DBD, dan cara pencegahan penularannya di rumah dan lingkungan masing-masing yang disesuaikan dengan pendidikan yang mereka miliki. Sarana yang digunakan bisa melalui pengajian, pertemuan warga, sedangkan penyuluhan massal bisa dilakukan melalui media massa seperti TV, radio, majalah dan surat kabar. Melalui langkah ini petugas penyuluh kesehatan dari puskesmas menjadi ujung tombak dalam pemberantasan DBD.

\section{Kesimpulan}

Berdasarkan paparan diatas disimpulkan sebagai berikut preventif lebih baik dari pada kuratif dalam penanganan DBD. Layanan puskesmas yang selama ini lebih banyak dijalankan melalui kuratif (pengobatan) pada kasus DBD perlu ditingkatkan upaya preventifnya. Hal ini merupakan upaya peningkatan pelayanan kesehatan puskesmas untuk penanggulangan penyakit tropis demam berdarah dengue. Petugas penyuluh lapangan dalam kinerjanya perlu sampai pada output perubahan prilaku budaya bersih yang dapat berpengaruh terhadap upaya membatasi penyebaran DBD. Langkah ini dilakukan dengan menguatkan masyarakat pada aspek pengetahuan yang berimplikasi perubahan prilaku dan kebiasaan yang dapat mencegah DBD. Penggunaan pendekatan kearifan lokal juga perlu dioptimalkan dalam mengubah pola pikir dan pola prilaku dimana materi tersebut diberikan petugas puskesmas yang bersinergi dengan tokoh agama dan tokoh masyarakat. Berdasarkan kesimpulan diatas, disarankan pada 
kepala dinas kesehatan di kabupaten dan kota untuk meningkatkan pelayanan kesehatan preventif pada penanganan DBD dengan memberi tolok ukur kinerja petugas lapangan puskesmas untuk meningkatkan promosi kesehatan pada masyarakat yang beroutput perubahan prilaku dan pola pikir terhadap budaya bersih dalam upaya preventif penaggulangan DBD.

\section{Daftar Pustaka}

Atik,dan ratminto. 2005. Manajemen Pelayanan, disertai dengan pengembangan model konseptual, penerapan citizen's charter dan standar pelayanan minimal. Yogyakarta: Pustaka Pelajar.

Guzman MG. 2002. Effect of age on outcome at secondary dengue infections. International Journal of infectious Disease. 6 (2): 118-124

Komariah., S. Pratita, dan T. Malaka. 2010. Pengendalian Vektor. Jurnal Kesehatan Bina Husada. Vol. 6, No. 1. Hal: 34-43.

Miles. Matthew B dan Michael A. Huberman. 1992. Analisis Data Kualitatif. JakartaUi Press

Pan American Health Organization. Dengue and Dengue Hemorrhagic Fever in the Americas:Guidelines for Prevention and Control. Washington, DC: PAHO Science Public. 1994; (548): 3-70.

Sri Irmawati, H. Sultan M., dan Nurhannis. Kualitas Pelayanan Kesehatan Di Puskesmas Sangurara Kecamatan Tatanga Kota Palu. https://media.neliti.com/media/publications/157122-ID-kualitaspelayanan-kesehatan-di-puskesma.pdf

World Health Organization. Dengue Hemorrhagic Fever. 1997. Diagnosis, Treatment, Prevention and Control. 2nd edition. Geneva; Available at: www. who. Who/emc / diseases/ Ebola / Dengue publication/index.html (accessed 20th December 2017).

http:/ / www.depkes.go.id / article/print/16030700001/wilayah-DBD-dbd-ada-di11-provinsi. html) 